\title{
Reform and Development of College English Education Yuanyuan Song
}

\author{
School of Foreign Studies, Xi'an University, Xi'an, 710065, China
}

\begin{abstract}
Keywords: college English teaching, current situation, necessity, problems, reform anddevelopment
\end{abstract}

\begin{abstract}
With the rapid economic development, especially after joining the WTO, our country has obtained more opportunities to communicate with other countries.As the major language tool in the world, the function of Englishbecomes more and more prominent.Therefore, our country has a higher demand for the English level of college students, and at the same time has great expectations for the college English teaching.College English teaching has made great progress in recent years, but it is far from satisfactory.At present, there are some problems in college English teaching, such as ignoring students 'subjective feelings, ignoring students' interest towards English learning, dumb English and so on, which are hindering the progress of English learning.We need to find out effective ways to solve these problems; hence the reform and further development of college English education is imminent.
\end{abstract}

\section{Introduction}

English is one of the most widely used languages in the world and has become an important tool for international communication and cultural and technological exchange.The establishment of college English course in Chinese higher education is conducive to the further development of college students, improving the international education level, as well as enhancing the international competitiveness of our country and the international communication skills of the younger generation. As the basic course for college students, college English has a large number of learners, wide range of involvement and profound influence[1].After entering the 21st century, college English teaching in China has undergone a complicated development process.Paying attention to and constantly improving college English teaching is an important way to train English language talents, and is necessary to improve the quality of higher education.

\section{The current situation of college English teaching}

With the full-scale implementation of the English curriculum reform in the basic education stage, the English level of high school graduates has been greatly improved;the English level of some students in high school has been equivalent to Level II or III of college English.It was suggested to complete foreign language education in the basic education stage, and even to abolish the college English course.However, the investigation found that only a very few colleges and universities can appropriately reduce English teaching; most colleges and universities should still further reinforce the college English teaching.In terms of teaching objectives, for most colleges and universities, the teaching objectives are no longer limited to the pass rate of College English Test Band 4 and Band 
6,but the comprehensive application ability and comprehensive quality of students as the most important teaching objectives.This reflects the fact that college English teaching is developing according to the requests of "classified guidance" and "individualized teaching" suggested by "The Curriculum Requirements", which is one of the important outcomes of college English teaching reform. In terms of teaching contents, most colleges and universities believe that improving the basic knowledge of English language and basic Englishskills is the most important.Among the five skills of listening, speaking, reading, writing and translating, listening, reading and speaking receive more attention.Considering the situation that college students' listening and speaking ability is weaker as a result of reading comprehension-based college English teaching, college English teaching reform emphases onenhancing the training of listening and speaking ability.Then reading as the main way tolearn language knowledge and cultural information, is the prerequisite and basis for listening and speaking.

"The Curriculum Requirements" proposes that the colleges and universities should design an English course system that suits their actual situation, providing various compulsory courses and elective courses so as to ensure that the English proficiency of different studentscan be fully trained and improved.The survey shows that in our country, college English courses are classified as compulsory and elective courses. The compulsory credits of college English in basic stage is mainly between 13 and 16 points, and more and more colleges and universities are gradually reducing the ratio of compulsory courses.At present, most of college English courses in China are universal; many colleges and universities hope to combine the characteristics of schools and majors to design personalized English courses. Thus according to the requests of "classified guidance" and "individualized teaching" suggested by "The Curriculum Requirements", college English courses should strive to meet the needs of schoolsand students' personal development.

In the reform of teaching mode, multimedia projection equipment used by teachers toassist teaching in classroom has been popular to a large extent.Although some schools have implemented the new teaching mode of "face-to-face teaching in classroom + computer-assisted instruction", classroom face-to-face teaching is still the major form of teaching.This indicates that there is still a lot of work to do to achieve the teaching mode of combining face-to-face teaching in classroom with computer-assisted autonomous learning as proposed by "The Curriculum Requirements".Given the effectiveness of different classroom teaching methods, the teachers have realized the importance of self-learning with the assistance of online teaching platform. The combination of teaching by teachers, appropriate language practice in classroom and online teaching platform for selflearningcan effectively improve the quality of teaching[2].

The new teaching mode emphasizes on the use of network technology, and the application of multimedia courseware plays an important role. Most schools possess and use their own multimedia network resources, but in different schools, the sources of resources are also different; most of the resources are from the publishing house, and few schools independently develop their own network resources. Most of the schools are using multimedia courseware provided by the publishing house, but the courseware undergo secondary development by many institutions of higher education. This indicates that the multimedia courseware provided by the publishing house is recognized by most 
schools, but over-reliance on these coursewares may not meet the specific needs of the students, and cannot effectively improve the teachers' ability to apply educational technology.Further data analysis shows that while many schools mainly use multimedia courseware provided by publishers, considerable universities of Project 211 and 985 use courseware developed by themselves compared to non-Project 211 universities.

At present, the education background of college English teachers in China has been remarkablyimproved compared with the past, but still has a big gap compared with other teacher team in which doctors are considerably prevalent. The imbalance of gender, title and education background of college English teachers affects the professional development of teachers and is not conducive to improving the quality of education and teaching[3].College English teachers have the heavy task of teaching basic courses, and their capacity to conduct scientific research is weak. A small number of teachers published academic papers and apply for research project.The current teacher evaluation system is not conducive to the career development of teachers.

\section{The necessity of reform}

Since the founding of the People's Republic of China,college English teaching has undergone several reforms, and experienced a series of changes from improving reading ability to improving English application ability, from traditional classroom teaching to combining computer and classroom teaching, from teacher-centered to student-centered teaching.Since the 1980s, the development of Chinese college English education has gone through two stages. In the first stage, "The College English Teaching Syllabus" promulgated and implemented in 1985-1986 changed the situation that there was no uniform goal for college English teaching, or unified examination in the past.The syllabus revised in 1999 proposed that passing the College English Testshould be the basic requirement for the students in national colleges and universities. In the second stage, the Ministry of Education in 2004 promulgated the"College English Curriculum Requirements"to carry out a nationwide reform of college English teaching. The core of the reform is to change the status of teaching for examination and improve students' comprehensive English ability.

There are differences and mismatch between the college English teaching objectives and the society actual demands. So far, college English education is based on uniform standards with unified teaching syllabus, mode, specifications and objectives.Although these have greatly promoted the development of college English education in our country, the colleges and universities in our country are facing an important problem that they cannot meet the needs of market diversification because of socio-economic development.

The efficiency cost of college English teaching is difficult to adapt to the trend of current education development.College English teaching is divorced from basic English teaching. The undergraduates spend a lot of time in learning foreign language with inefficiency, leading to frustrationand wasting teaching resources of colleges and universities.

The concepts and mode of college English teaching is difficult to adapt to the trend of current education development.A part of teachers are of backward teaching ideas as well as a single and old 
teaching mode. They are in favor of teachers-centered teaching, and do not know to make full use of multimedia in teaching.

\section{Reform of college English teaching}

Teaching with multimedia networking challenges the traditional teaching idea and mode; the process of educational reform is a process of development and update of teaching concept.The traditional education concept emphasizes on teachers' teaching, ignoring the subjective role of students. The multimedia network will replace part of the teacher's role.Therefore, teachers need to update the traditional teaching concept, study the profound connotation of "teaching" and "learning", carry out the "student-centered" and "process-centered" policy in teaching, and establish equal relationship between teachers and students, correctly understand the role of teachers in teaching activities, and teach students appropriate learning methods and strategies.In addition, teachers should make full use of network resources, and constantly update their teaching methods.

Based on their development history and characteristics, the colleges and universities should establish curriculum system of "compulsory English course + elective English course + professional English course " according to the teaching objective set by the Teaching Syllabus, in order to develop the comprehensive English proficiency of students, enhance their listening and speaking ability, and improve their cultural knowledge and cultural quality. The new curriculum system should pay attention to comprehensive English proficiency of students; while emphasizing on the basic knowledge of language, we should focus on students' English listening and speaking ability and application ability, and improve the students' comprehensive quality.

The colleges and universities should determine the guiding ideology of teaching based on the actual conditions of students and the requirements of the society for English major students, establishing a student-centered teaching mode, combining network-based autonomous learning and classroom teaching with the aim of fostering students' comprehensive language application ability and self-learning ability[4].The colleges and universities should try various teaching methods, such as communicative teaching method, task-based teaching method and interactive teaching method.Students should be taken as the center of teaching, use learned knowledge and practice their language skills,improve their comprehensive English application ability to achieve the optimal outcomes.

Traditional teaching assessment is a summative assessment at the end of the semester, which only reflects the results of students' learning, ignoring the their development and progress during the learning process, seriously affecting the overall development of students. The scientific evaluation system should combine the summative evaluation with the formative evaluation to construct a new evaluation system[5].In the context of network-based learning, formative evaluation is a very important part of the teaching evaluation system. It examines students'learning process and attendance, and whether they participate in classroom activities. Extracurricular English learning and online learning are both important to assess students' academic performance.The evaluation includes students' self-evaluation, mutual evaluation between groups and evaluation by teacher 
etc.Formative evaluation is conducive to the interaction between teachers and students, providing a broad space for students' independent learning and development.

Teachers are the organizers and planners of teaching activities. English teachers should pay attention to their own learning and improvement, and actively participate in scientific research activities.The colleges and universities should organize various English trainings for teachers, to discover the actual problems in teaching, and achieve the student-centered and teacher-oriented teaching under the network environment.

\section{Conclusion}

English is an important tool for international communication and exchange of culture and technology. College English courses are conducive to the further development of undergraduates and improvement of the international education level.College English teaching has made great progress in recent years, but it is far from satisfactory. At present, there are some problems in college English teaching, and we need to find out effective ways to solve these problems; hence the reform and further development of college English education is imminent.College English teaching reform has a certain practical significance in improving the overall quality of college English teaching and training high-quality English talent.

\section{References}

[1] The Department of Higher Education, the Ministry of education of the People's Republic of China. College English Curriculum Requirements. [S]. Beijing; 2007.

[2] Hai-Xiao Wang. An analysis of college English teachers and teaching. [J]. Foreign Language World, 2009(4): 6-13.

[3] National medium and long-term education reform and development plan(2010-2020).[S]. Beijing:People's Publishing House, 2010.

[4] Ding-Fang Shu. Reform of foreign language teaching: problems and countermeasures[M]. Shanghai: Shanghai Foreign Language Education Press, 2004.

[5] Jie Zhang. Globalization of language: Integration and diversification[J]. Foreign Language, 2002(6). 